\title{
The Tectonic Background of Basement Metamorphic Rocks and Its Relationship to Uranium Source Layer, Xiangshan Uranium Ore Field
}

\author{
Xiaoliang Zhang ${ }^{1, a}$, Qingkun Yang ${ }^{2, b}$, Yang Zeng, ${ }^{3, c}$, Hongjian $\mathrm{Qu}^{2, \mathrm{~d}}$, Wanpeng \\ Zhou ${ }^{2, \mathrm{e}}$, Zehuang $\mathrm{RaO}^{4, \mathrm{f}}$ \\ ${ }^{1}$ China University of Geoscieces(Beijing), Beijing, China \\ ${ }^{2}$ Fundamental Science on Radioactive Geology and Exploration Technology Laboratory, East China \\ Institute of Technology, Nanchang, Jiangxi, China \\ ${ }^{3}$ Jiangxi copper co.,LTD in wushan copper mine Jiujiang, China \\ ${ }^{4}$ Nuclear industry geological bureau of JiangXi province brigade two hundred sixty-one, YingTan, \\ China
}

a105714928@qq.com,b197267245@qq.com,c280508017@qq.com,,15420250@qq.com,

e1249716660@qq.com,,58084590@qq.com

Keywords: Qingbaikou system; Remnant ocean; Uranium source layer; Xiang shan

Abstract. The geochemistry of metamorphic sedimentary rocks from Qingbaikou system in Xiangshan area indicate that : the $\mathrm{Al}_{2} \mathrm{O}_{3} / \mathrm{SiO}_{2}$ is $0.13 \sim 0.23$, equal to or slightly lower than the standard greywacke. In" $\sum \mathrm{REE} / 10-6-\mathrm{La} / \mathrm{Yb}^{\prime}$ diagram, the investment point is in Sandy Rock and greywacke range, indicating that the original rock of metamorphic rocks are mainly medium maturity sandstone or graywacke. $\mathrm{TFe}_{2} \mathrm{O}_{3}+\mathrm{MgO}$ is $12.6 \% \sim 9.78 \%$, between the island arc and active continental margin type sandstone composition. The "Hf-La/Th" and " $\mathrm{Fe}_{2} \mathrm{O}_{3}+\mathrm{MgO}$ and $\mathrm{TiO}_{2}$ and $\mathrm{Al}_{2} \mathrm{O}_{3} / \mathrm{SiO}_{2} "$ diagram, indicates they formed in active continental margin or island arc related sedimentary basin. Previous studies show that in the $855 \sim 826 \mathrm{Ma}$ between the Cathaysian plate and the Yangtze plate has completed the splice of the eastern section, a large amount of S type granites formed in the process, which predates the basement metamorphic sedimentary rock formation age (810 806Ma). S type granite in this period are mainly distributed in the southeastern margin of the Yangtze plate, none in the Cathaysian plate area, but Xiangshan metasedimentary rocks exist a lot of magmatic zircons in this period, illustrating that in the the two plates subduction process, Cathaysian plate edge early formed island arc or back arc basin, then gradually evolved into remnant ocean basin, began to receive from the Yangtze plate terrigenous clastic. Metamorphic sedimentary rocks and volcanic basement intrusive have similar REE chondrite distribution pattern, but $\mathrm{Pb}-\mathrm{Sr}-\mathrm{Nd}$ isotope values and $\mathrm{Nd}$ model ages (volcanic intrusive complex of T2DM is $1.66 \mathrm{Ga}$ in average, and metasedimentary rocks is $2.17 \mathrm{Ga}$.) are different. In the "t(Ma)- $\varepsilon \mathrm{Nd}(\mathrm{T})$ " and " ${ }^{143} \mathrm{Nd} /{ }^{144} \mathrm{Nd}-1 / \mathrm{Nd}\left(10^{-6}\right) "$ diagram and $\mathrm{Pb}$ isotope growth curve, the two cast in different regions, indicating that there are not too much relationship between them. In the deep of Xiangshan, there should be a source of uranium storage, but not basement metamorphic rocks, in the diagenesis process, the rock magma and the reservoir happened mixing together and come into being the complex rock mass.

\section{Introduction}

The Xiangshan uranium deposit has been discovered more than half a century of history, it is geographically located in the northeastern margin of the Cathaysia plate,and the east segment of Jiangnan orogenic belt.There are Xiangshan,Shengyuan,Dazhou and other dozens of uranium deposits in the segment,and all of these uranium deposits have similar basement metamorphic rocks.The understanding of " the Cathaysia plate and the Yangtze plate have been eventually conjunct in the indo-chinese epoch" has been the unanimous recognition ${ }^{[1-5]}$,but there is not yet a unified understanding about Whether there was a same experience in the Precambrian ${ }^{[7-10,5]}$.The research degree of the former study about the Qingbaikouan System's basement meta sedimentary rocks are mainly concentrated in the diagenesis structure background of original rock--formed in the 
island-arc environment of an active continental margin ${ }^{[11]}$, the stable craton continental shelf of the neritic environment ${ }^{[12]}$, and the relationship with the surrounding magmatic rocks(described below). The study found that there are residual zircons spanning from 780 to $2680 \mathrm{Ma}$, when dating residual zircons La-ICPMS U-Pb of the basement meta sedimentary rocks(unpublished).In this paper,we started from lithogeochemical characteristics and residual zircon age of etamorphic rock in Xiangshang, and combined with the age and the distribution characteristics of S-type granites in this area,to judge that whether it is cracking between the Cathaysia and Yangtze plate ,furtherly.Most geological scholars hold that the volcanic-intrusive complex rocks of Xiangshan uranium orefield are mainly from partial melting of basement metamorphic $\operatorname{rock}^{[13-20,7]}$, and the uranium source layer of Xiangshan uranium orefield is basement metamorphic rock, uranium has the migrated trend that was from high-grade metamorphose to low metamorphose, and it precipitated and enriched on the favorable horizon,so then the uranium source layer was formed.Furtherly, this uranium source layer turned to volcano-intrusive complex with regionally remelting, and leached out uranium from surrounding rocks when the late hydrotherm was intruding, and finally it precipitated uranium deposits on favorable parts ${ }^{[21-22,18]}$. But the proof of the relationship between volcano-intrusive complex and basement metamorphic rocks was concluded from former research conclusion which is that "complex rocks are from partial melting material of crust,or it was according to that they have the similar "chondrite-normalized plots of REE", there are rare detailed study between the two.So studying the relationship betwenn the the composition of protolith and the genetic environment of metamorphic series and volcano-intrusive complex rocks is very important to the recognition that is about the crustal evolution and the mineralization of uranium and other metals in this area.

\section{General geology}

Xiangshan volcanic basin is geographically located in the northeastern margin of HunanGuangxi-Jiangxi plate of the south China plate, and at the south side of Qin-Hang bonding zone, and it is gone through by Suichuan-Dexing deep fault at NW side(Fig. 1). The volcanic basin is nearly oval on the plane, and it is infundibuliform that is south-north symmetry and steep in the east and sustained in the west on the profile.Basin basement is mainly metamorphic rocks of Qingbaikou system's low greenschist facies;lithology is mainly including phyllite, fine biotite schist,fine garnet-mica schist and medium-coarse garnet-mica schist;and it has lower carboniferous and upper triassic coal bearing formation.

Basin main rock is a set of lower cretaceous volcanic-sedimentary rocks, and was intruded by shallow-ultrashallow intrusive rocks(rhyodacitic porphyry,macro-porphyritic granite-porphyry and orphyraceous granite)what were formed after volcanic rocks.Volcanic-sedimentary rocks have Daguding formation $\left(\mathrm{K}_{1} d\right)$ and Ehuling formation $\left(\mathrm{K}_{1} e\right)$. The lower member of Daguding formation 


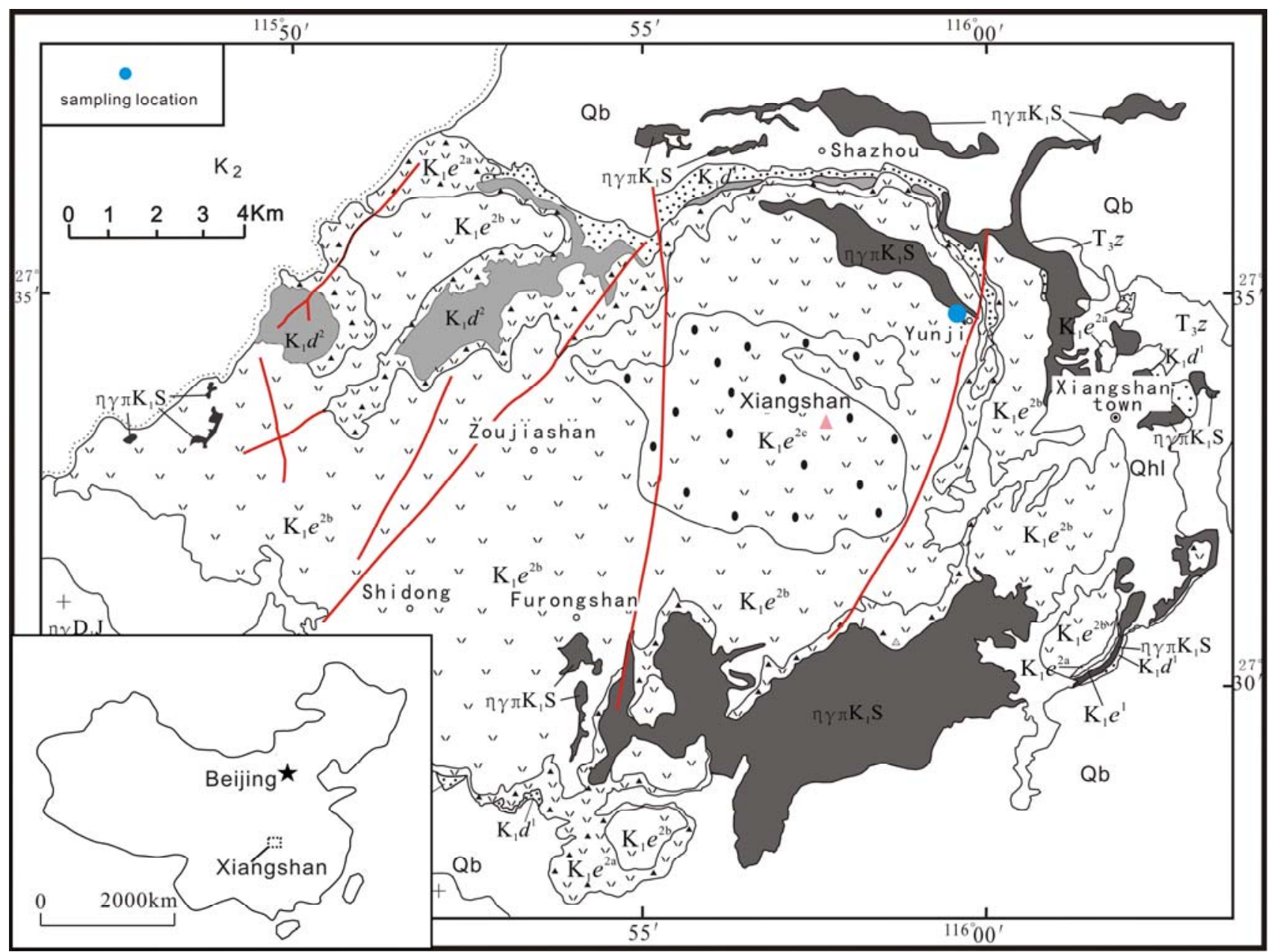

Fig.1 Geology aspects of Xiangshan volcano basin and sampling locations

$\mathrm{Qh}_{\mathrm{hl}}$ : Lianyu formation; $\mathrm{K}_{2}$ :the late cretaceous red beds; $\mathrm{K}_{1} \mathrm{e}^{2} \mathrm{c}$ : porphyroclastic lava containing graniticmass xenoliths at the second member's central facies of early Cretaceous Ehuling formation; $\mathrm{K}_{1} \mathrm{e}^{2} \mathrm{~b}$ : porphyroclastic lava at the second member's transitional facies of early Cretaceous Ehuling

formation; $\mathrm{K}_{1} \mathrm{e}^{2} \mathrm{a}$ : porphyroclastic lava containing metamorphic breccia at the second member's marginal facies of early Cretaceous Ehuling formation; $\mathrm{K}_{1} \mathrm{~d}^{2}$ : inninmorite at the second member of

early Cretaceous Daduding formation; $\mathrm{K}_{1} \mathrm{~d}^{1}$ : the first member of early Cretaceous Daguding

formation; T3z: metamorphic rocks in Zijiashan formation of late Triassic; $\eta \gamma \pi \mathrm{K}_{1} \mathrm{~S}$ : the macro-porphyritic monzonitic granite-porphyry or the porphyraceous micro fine adamellite of the Shazhou unit of early Cretaceous; $\eta \gamma \mathrm{D}_{1} \mathrm{~L}$ : the coarse grained porphyritic biotite granite at Le'an unit of the early Devonian; $\eta \gamma \mathrm{D}_{1} \mathrm{~J}$ : the fine grained biotite granite at Jiaoping unit of the early Devonian;

BX: hydrothermal breccia(cryptoexplosive breccia);

has mauve conglomerate,sandstone,siltstone,crystal tuff clamping rhyolite mass, fine sandstone, grey tuff and rhyolite;and the upper segment has inninmorite.The lower member of Ehuling formation has mauve tuffaceous siltstone,sandstone,fine sandstone, grey tuff and ignimbrite; the upper segment has porphyroclastic lava.Porphyroclastic lava is a kind of granitic rock which has mortar texture,and it is a kind of transitional rock that has both ultra-shallow intrusions' characteristic and ejection's characteristic,we call it intrusive vein ${ }^{[16-19]}$. There is upper cretaceous mauve clastic stone on the basin's volcanic rocks above. The distribution of uranium deposits and its mineralized points is mainly in the north and west,and lead-zinc mine formed in $700 \mathrm{~m}$ below, and there is a growing trend from it downward.

\section{Sample collection and analysis method}

In this paper,the object of the research is mainly about metamorphic sedimentary rock,and the samples are mainly collected from Yunji area in the north of Xiangshan,including sericite- phyllite 
and quartz hornfels, and quartz hornfels are xenoliths of porphyroclastic lava among the samples.There are 5 samples that were analysed by major element and trace element of whole rock, and there are 5 samples that were analysed by $\mathrm{Pb}-\mathrm{Sr}-\mathrm{Nd}$ isotope.The major element and trace element of whole rock were analysed on CNNC Beigjing Research Institute of Uranium Geology,the detail analysis process can be checked in the paper by Liu Hanbin, et al ${ }^{[23]}$, data are presented in Table 1 and table 2.Pb-Sr-Nd isotope was analysed on CNNC Beigjing Research Institute of Uranium Geology, the detail analysis process can be checked in the paper by Guo Dongfa,et al ${ }^{[24]}$.Conditions of $\mathrm{Rb}$ and Sr:mass fractionation is corrected by ${ }^{86} \mathrm{Sr} /{ }^{88} \mathrm{Sr}=0.1194$, the result of standard measurement:NBS987 is $0.710250 \pm 7$, laboratory process background: $\mathrm{Rb} 2 \times 10-10 \mathrm{~g} \mathrm{Sr}$ $2 \times 10^{-10} \mathrm{~g}$; condition of Sm and $\mathrm{Nd}$ :mass fractionation is corrected by ${ }^{146} \mathrm{Nd} /{ }^{144} \mathrm{Nd}=0.7219$, the result of standard measurement:JMC is ${ }^{143} \mathrm{Nd} /{ }^{144} \mathrm{Nd}=0.512109 \pm 3$. The whole process background:Sm $\mathrm{Nd}<50 \mathrm{pg}$;Pb isotope measurement.Isotopic analysis was done by ISOPROBE-T thermal ionization mass spectrometer,touch the rhenium belt by phosphoric acid silica gel to put the samples on it , and then measure $\mathrm{Pb}$ isotopic by static accepted method.NBS981 result was not corrected: ${ }^{208} \mathrm{~Pb} /{ }^{206} \mathrm{~Pb}=2.164940 \pm 15,{ }^{207} \mathrm{~Pb} /{ }^{206} \mathrm{~Pb}=0.914338 \pm 7,{ }^{204} \mathrm{~Pb} /{ }^{206} \mathrm{~Pb}=0.0591107 \pm 2$, the whole process background $\mathrm{Pb}<100$ pg.data are presented in Table 3 .

\section{Results and Discussion}

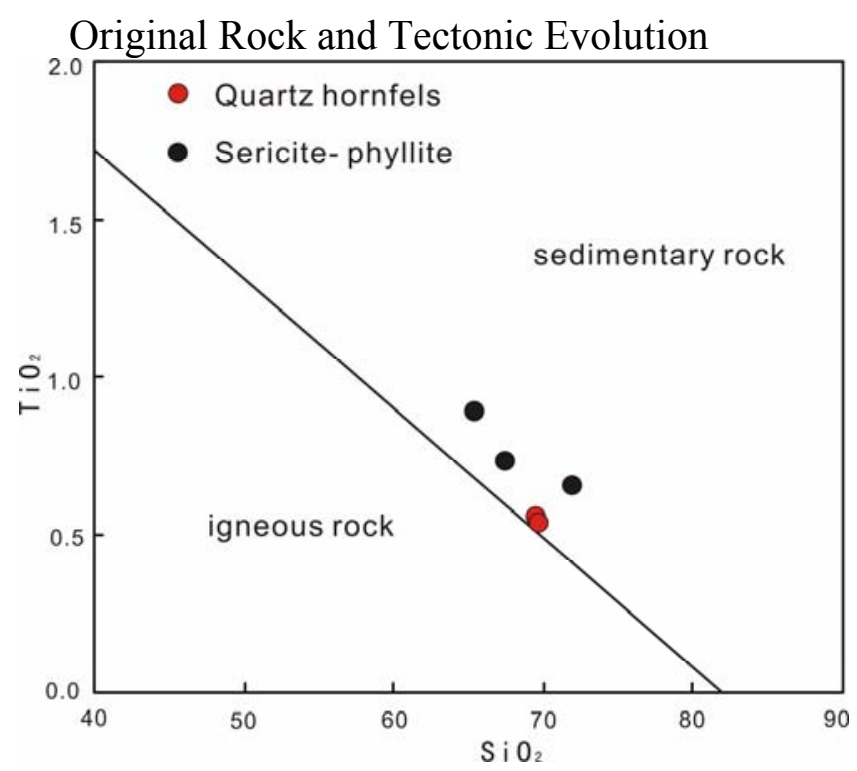

Fig. $2 \mathrm{SiO}_{2}(\mathrm{wt} \%)-\mathrm{TiO}_{2}(\mathrm{wt} \%)$ diagram

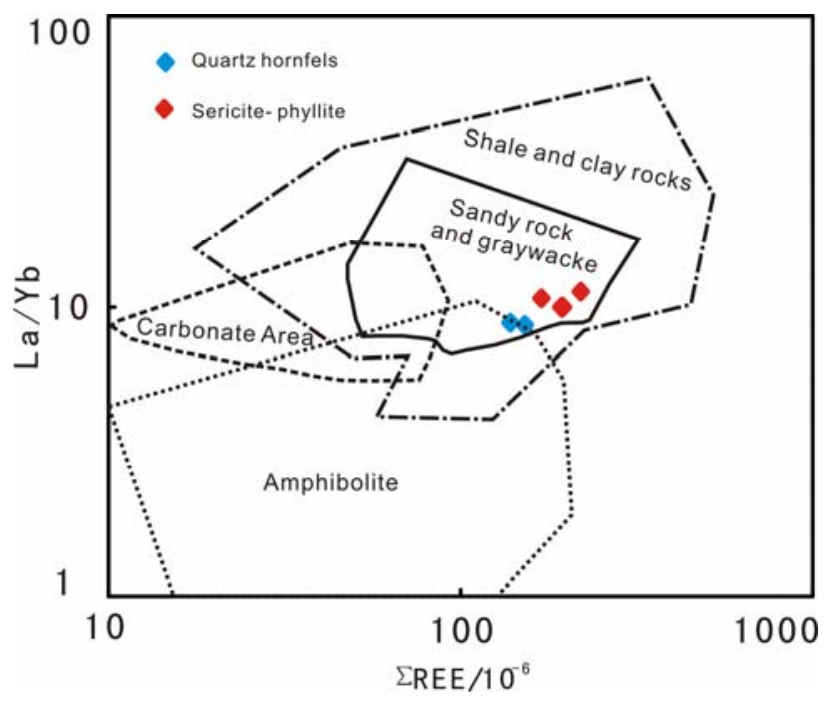

Fig.3 $\sum$ REE/10-6-La/Yb diagram

Among the major elements of the basement meta sedimentary rocks, the content of $\mathrm{SiO}_{2}$ is $71.94 \% \sim 67.46 \%$, the average content is 68.776 ; the content of $\mathrm{TiO}_{2}$ is $0.54 \% \sim 0.89 \%$, the average content is $0.67 \%$; the content of $\mathrm{Al}_{2} \mathrm{O}_{3}$ is $9.07 \% \sim 15.2 \%$, the average content is $11.92 \% ; \mathrm{Al}_{2} \mathrm{O}_{3} / \mathrm{SiO}_{2}$ is $0.13 \sim 0.23$, the average ratio is 0.17 , it is less than or equal to the content $(0.2 \sim 0.23)$ of standard graywacke which was put forward by Roser \& Korsh ${ }^{[25]}$,all of those show that the maturity of Xiangshan meta sedimentary rocks is between sandstone and graywacke. The ratio of $\mathrm{Th} / \mathrm{Sc}$ is $0.82 \sim$ 1.21 , and the average ratio is 0.99 , and it is close to upper crust' $\mathrm{s}(1.0)$ (Taylor \& $\mathrm{M}$ clennan, 1985).Combine with the two figures of $\mathrm{SiO}_{2}-\mathrm{TiO}_{2}$ (Fig.2) and $\sum \mathrm{REE} / 10^{-6}-\mathrm{La} / \mathrm{Yb}$ (fig.3), we can see that the original rock of Xiangshan Qingbaikou system should be sandstone or graywacke which has medium maturity. $\mathrm{TFe}_{2} \mathrm{O}_{3}+\mathrm{MgO}$ is $12.6 \% \sim 9.78 \%$, and the average sum is $10.84 \%$, and its content changing is within a large range,it is between island-arc type and active continental-margin sandstone' $\mathrm{s}^{[26]}$.

Bhatia $^{[26-27]}$ divided fragments into four kinds of tectonic environment according to their different source region(such as oceanic island arc,continental island arc, active continental margin and passive 
continental margin, and he held that composition of sandstone and plate tectonic environment have the relationship below:
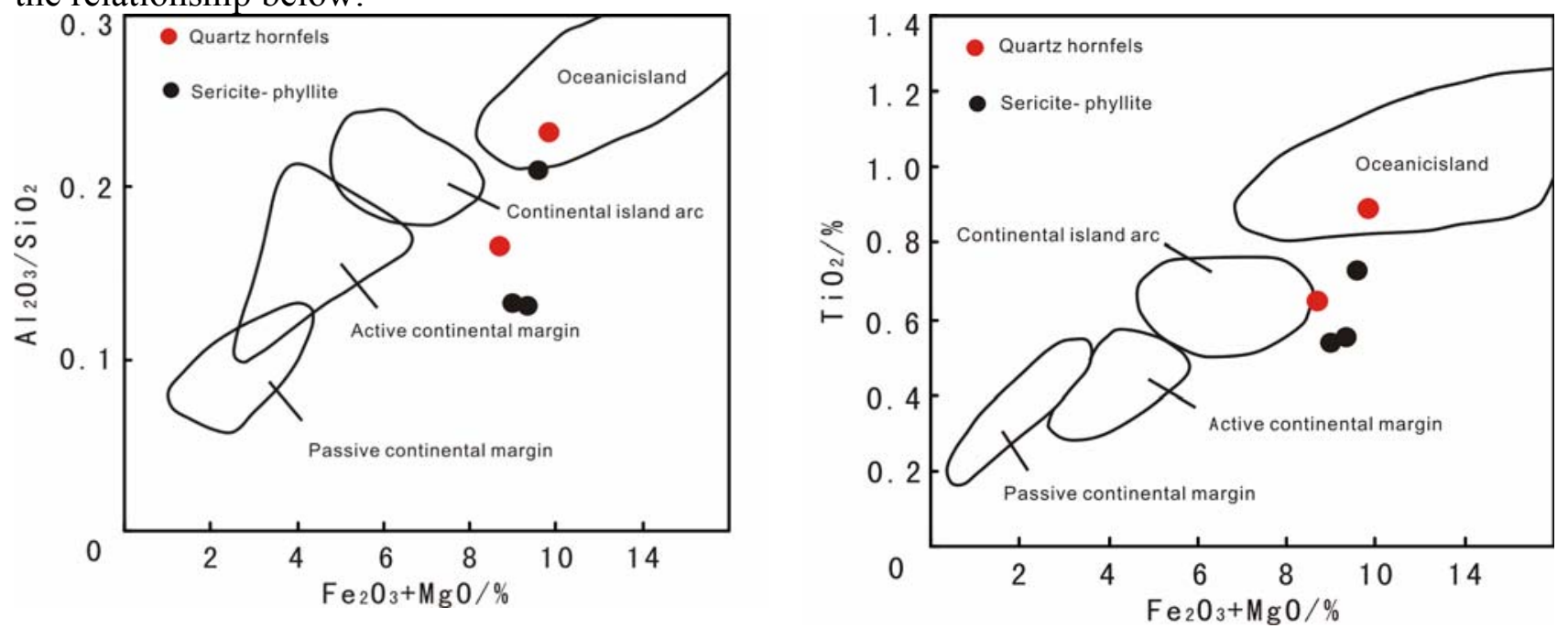

Fig.4 $\mathrm{Fe}_{2} \mathrm{O}_{3}+\mathrm{MgO}(\mathrm{wt} \%)-\mathrm{Al}_{2} \mathrm{O}_{3} / \mathrm{SiO}_{2}$ diagram Fig.5 $\mathrm{Fe}_{2} \mathrm{O}_{3}+\mathrm{MgO}(\mathrm{wt} \%)-\mathrm{TiO}_{2}(\mathrm{wt} \%)$ diagram

The content of $\mathrm{Fe}_{2} \mathrm{O}_{3}+\mathrm{MgO}$ and $\mathrm{TiO}_{2}$ among major elements and the ratio of $\mathrm{Al}_{2} \mathrm{O}_{3} / \mathrm{SiO}_{2}$, $\mathrm{K}_{2} \mathrm{O} / \mathrm{Na}_{2} \mathrm{O}$ and $\mathrm{Al} 2 \mathrm{O} 3 /\left(\mathrm{CaO}+\mathrm{Na}_{2} \mathrm{O}\right)$ are the most significant parameters of judging tectonic environment.From an oceanic island arc, continental arc and active continental margin to passive continental margin, the content of $\mathrm{Fe}_{2} \mathrm{O}_{3}+\mathrm{MgO}$ and $\mathrm{TiO}_{2}$ and the ratio of $\mathrm{Al}_{2} \mathrm{O}_{3} / \mathrm{SiO}_{2}$ decreases, and the ratio of $\mathrm{K}_{2} \mathrm{O} / \mathrm{Na}_{2} \mathrm{O}$ and $\mathrm{Al}_{2} \mathrm{O}_{3} /\left(\mathrm{CaO}+\mathrm{Na}_{2} \mathrm{O}\right)$ increases. Variation diagram(Fig.4,Fig.5) of $\mathrm{Fe}_{2} \mathrm{O}_{3}+\mathrm{MgO}-\mathrm{Al}_{2} \mathrm{O}_{3} / \mathrm{SiO}_{2}$ and $\mathrm{Fe}_{2} \mathrm{O}_{3}+\mathrm{MgO}-\mathrm{Al}_{2} \mathrm{O}_{3} / \mathrm{SiO}_{2}$ show that Xiangshan Qingbaikou system metamorphic sedimentary rock relates with island arc-active continental margin environment.

The content of REE is stable in clastic sedimentary rocks, it was affected by weathering, diagenesis and metamorphism not obviously ${ }^{[28]}$,so that it can provide important constraints to the cause of sediment. The sandstone's trace element and REE content and ratio of relevant elements are clearly different from graywacke' $s$ in the four kinds of tectonic environment that were described by Bhatia ${ }^{[26-27]}$.From an oceanic island arc, continental arc and active continental margin to passive continental margin, the content of $\mathrm{La}, \mathrm{Ce}, \mathrm{Th}, \mathrm{U}, \mathrm{Hf}, \mathrm{EREE}$ and the ratio of $\mathrm{La} / \mathrm{Yb}$ and $(\mathrm{La} / \mathrm{Yb}) \mathrm{N}$ increase obviously, and $\delta \mathrm{Eu}$ decrease.In the figure of La/Th-Hf(Fig.6),most samples distribute into the area of acid island arc.Chondrite-normalized plots of REE(Fig.7) of Xiangshan metamorphic sedimentary rock is similar to graywacke of continental island $\operatorname{arc}^{[27]}$ and metamorphic sedimentary rock of continental marginal volcanic arc-back-arc basin environment ${ }^{[29]}$ in Aksu, the south west of Tianshan,Xinjiang,it shows that the metamorphic sedimentary rock of these study areas may form in active continental margin or continental island arc correlated sedimentary basin.

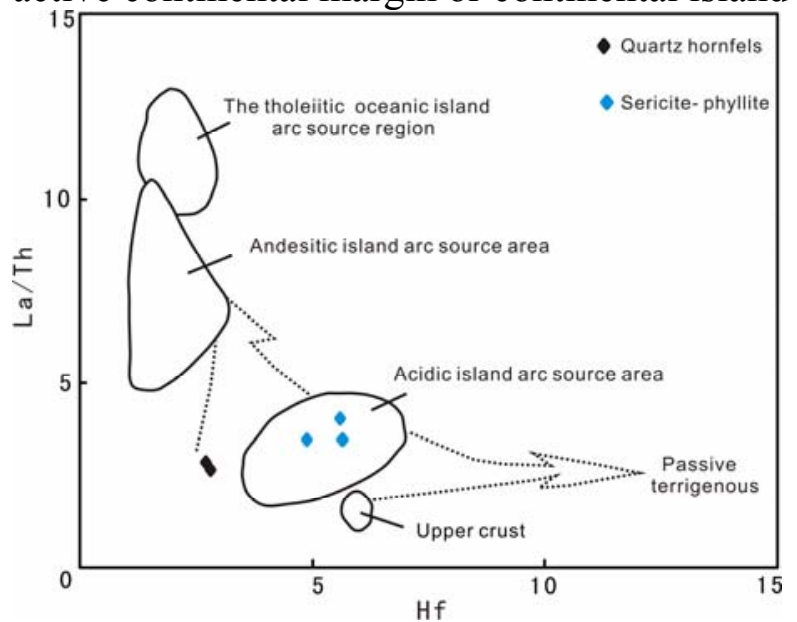

Fig.6 Hf-La/Th diagram

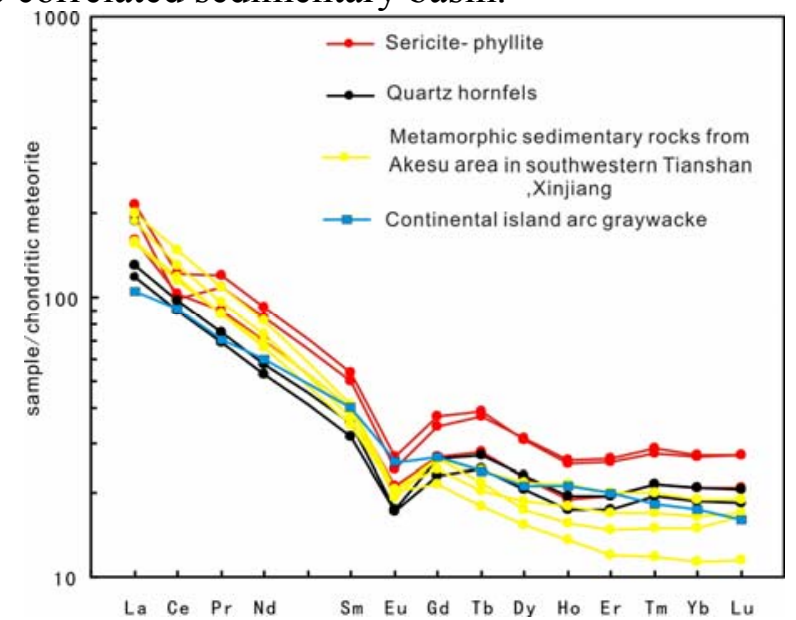

Fig.7 Chondrite-normalized plots of REE

But,the active continental margin which was mentioned in the paper by Bhatia ${ }^{[27]}$ referred to the active continental margin of andean-type, it is not the general active continental margin,not including 
the island arc like Japan Island ${ }^{[29]}$.So, in order to distinguish the tectonic setting of this metamorphic sedimentary rock furtherly,in this paper,we studied by immobile trace elements.In the figure of La-Sc-Th and Sc-Th-Zr/10(fig.8), almost all of sample distribute into the area of continental island arc except one sample, it shows that this set of rocks may deposited on the relevant basins that were nearby the continental island $\operatorname{arc}^{[26]}$.

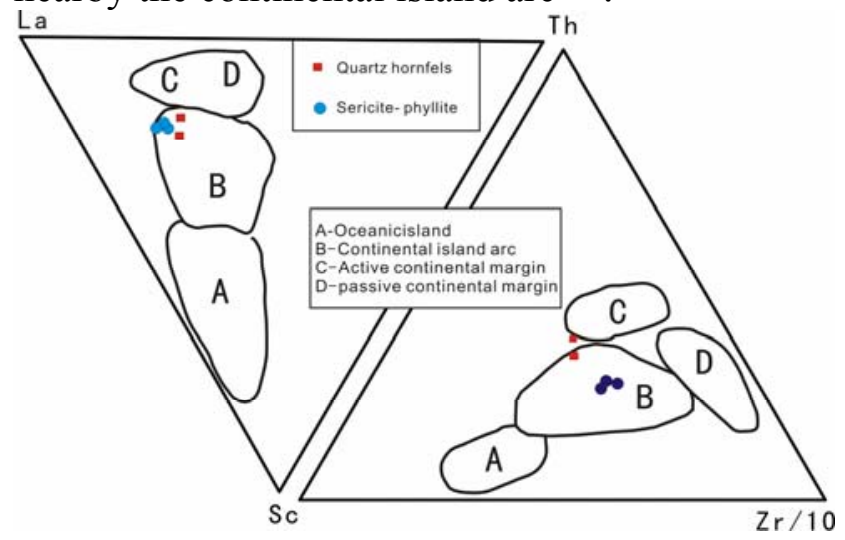

Fig. 8 the triangular figure of La-Sc-Th and $\mathrm{Sc}-\mathrm{Th}-\mathrm{Zr} / 10$

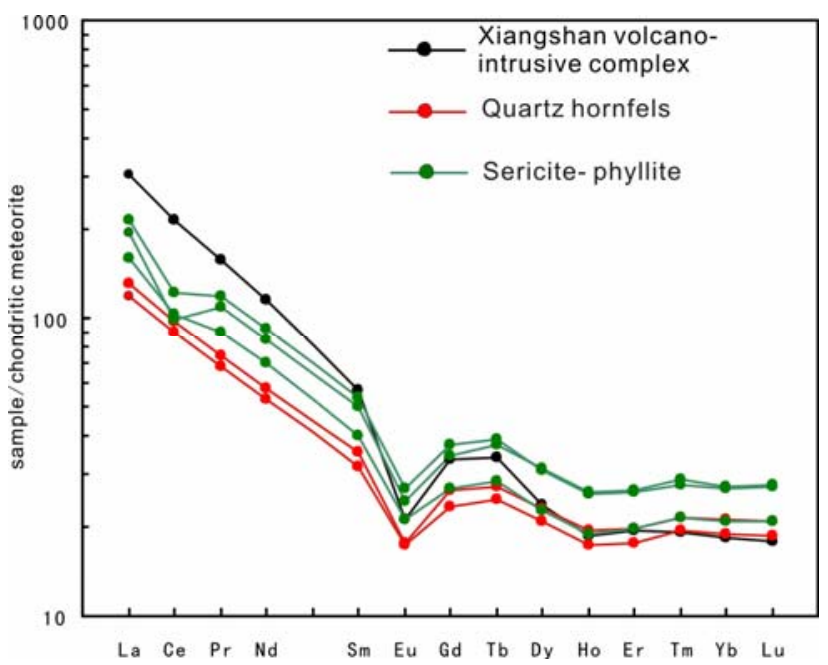

Fig. 9 Chondrite-normalized plots of REE

There are lots of S-type granite during 855 to $826 \mathrm{Ma}$ in new proterozoic in the east of Jiangnan orogenic belt,and Xue Huaimin et $\mathrm{a}^{[9]}$ held that Cathaysia plate and Yangtze plate were gradually closing in this period, and the period is earlier than the forming time of Qingbaikou system basement meta sedimentary rocks that is from 810 to $806 \mathrm{Ma}$ (unpublished). The S-type granitic exposure sites distribute in the south of Anhui and nearby the Yangtze craton, and it has not been discovered in the area of south Jiangnan orogenic belt of Cathaysia plate, but in the north of Cathaysia plate, Xiangshan basement meta sedimentary rocks received lots of this period's magmatic zircons.But the geochemical characteristics of Xiangshan basement meta sedimentary rocks show that the late Qingbaikouan Xiangshan basement meta sedimentary rocks formed in the sedimentary formation of island-arc-back-arc basin type,and it proves that there were some remnant-ocean basins inside inheriting the characteristics of active continental margin basin and receiving terrigenous clastic continue during 810 to $806 \mathrm{Ma}$,although Cathaysia plate and yangtze plate had collided.After that,the Cathaysian plate and the Yangtze plate cracked again during the upper Sinian to Cambrian period,so that the ancient South China Ocean was split ${ }^{[30]}$.

Relationship with Uranium

In the figure of Chondrite-normalized plots of REE(Fig.9), the former ${ }^{[17-20]}$ always held that meta sedimentary rocks and the ore bearing volcano-intrusive complex have the similar characteristics, and they are both in the rightist type of "gull" of LREE. The author compared the complex REE's average with meta sedimentary rocks' and found that there are certain difference between them,and the content of complex LREE is higher than the content of the basement metamorphic rocks' LREE.And there are two reasons that can lead to this, one is that the complex body is from the partial fusion of the basement metamorphic rocks, but the degree of partial fusion is low, and another is that the complex body is not from the remelting of the basement metamorphic rocks.

In the $\mathrm{Sr}$ isotope composition(table 3), the ore bearing volcano-intrusive complex' ${ }_{\mathrm{s}}{ }^{87} \mathrm{Sr} /{ }^{86} \mathrm{Sr}$ is $0.715345 \sim 0.724519$, and the average is 0.718575 ; the quartz hornstone' $\mathrm{s}{ }^{87} \mathrm{Sr} /{ }^{86} \mathrm{Sr}$ is $0.743914 \sim$ 0.743724 , the sericite-phyllite' $\mathrm{s}{ }^{87} \mathrm{Sr} /{ }^{86} \mathrm{Sr}$ is $0.879617 \sim 0.817627$, the average of the whole meta sedimentary rocks' is 0.8105262 . The meta sedimentary rocks and the volcano-intrusive complex body have great difference about the $\mathrm{Sr}$ isotope.

A part of scholars ${ }^{[31-34]}$ held that the composition of Sr was obviously affected by grain size of the sediments,chemical weathering and diagenesis etc. during the process of forming sediment,and weathering would have a certain influence on that after rock forming.Comparatively speaking, $\mathrm{Nd}$ 
was almost unaffected by external,Sm was fractionated during crust-manlte differential events, so that can be more reliably applied to study the material source of sediments ${ }^{[35-38]}$.

In the Nd isotope composition(Table 3), the ore bearing volcano-intrusive complex ${ }^{\prime} \mathrm{s}^{143} \mathrm{Nd} /{ }^{144} \mathrm{Nd}$ is $0.512006 \sim 0.512133$, the average is 0.512093 ; the quartz hornstone' $\mathrm{s}^{143} \mathrm{Nd} /{ }^{144} \mathrm{Nd}$ is $0.511751 \sim$ 0.511831 , the sericite-phyllite' $\mathrm{s}^{143} \mathrm{Nd} /{ }^{144} \mathrm{Nd}$ is $0.511718 \sim 0.511804$, the average of the whole meta sedimentary rocks' is 0.511767 . Similarly, the meta sedimentary rocks and the volcano-intrusive complex body have great difference about the $\mathrm{Nd}$ isotope. The $\mathrm{Nd}$ model ages (T2DM) of the ore bearing surrounding rocks--inninmorite,porphyroclastic lava,macro-porphyritic granite-porphyry and orphyraceous granite are close to each other,and it is during $1.67 \sim 1.63 \mathrm{Ga}$, and the average is 1.66Ga(unpublished), the $\mathrm{Nd}$ model age(T2DM) of the quartz hornstone xenoliths of phyllite and porphyroclastic lava is during $2.1 \sim 2.26 \mathrm{Ga}$ in the area,and the average is $2.17 \mathrm{Ga}$, the model ages of the volcano-intrusive complex and the basement metamorphic rocks have some certain difference,and in the $\mathrm{t}(\mathrm{Ma})-\varepsilon \mathrm{Nd}(\mathrm{t})$ figure(Fig.10), there is only one sample of complex body distributing in the area of the meta sedimentary rock.And in the ${ }^{14} 3 \mathrm{Nd} /{ }^{144} \mathrm{Nd}-1 / \mathrm{Nd}\left(10^{-6}\right)$ figure(Fig.11), the quartz hornstone and the sericite-phyllite have a similar range,and every lithology of complex body has a similar range, but the two ranges have no intersection.

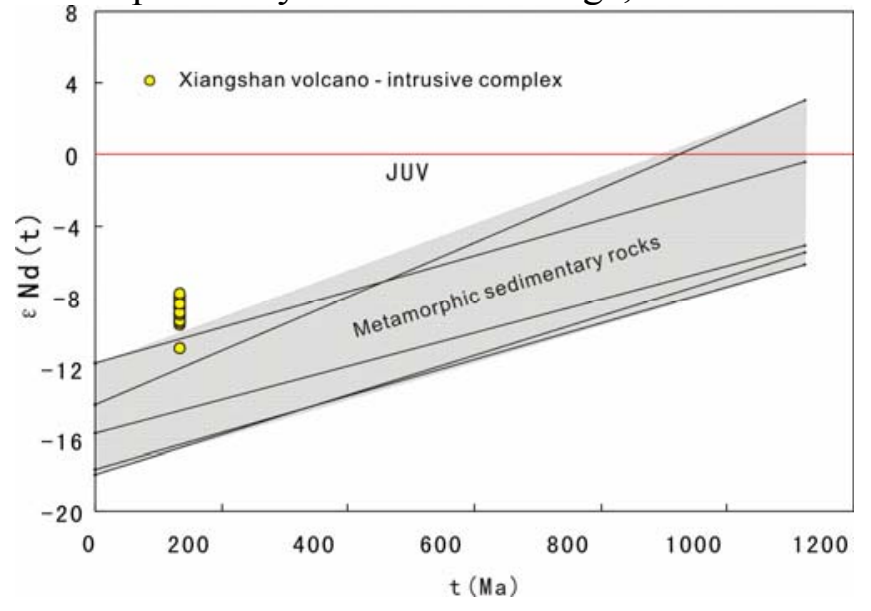

Fig. $10 \mathrm{t}(\mathrm{Ma})-\varepsilon \mathrm{Nd}(\mathrm{t})$ diagram

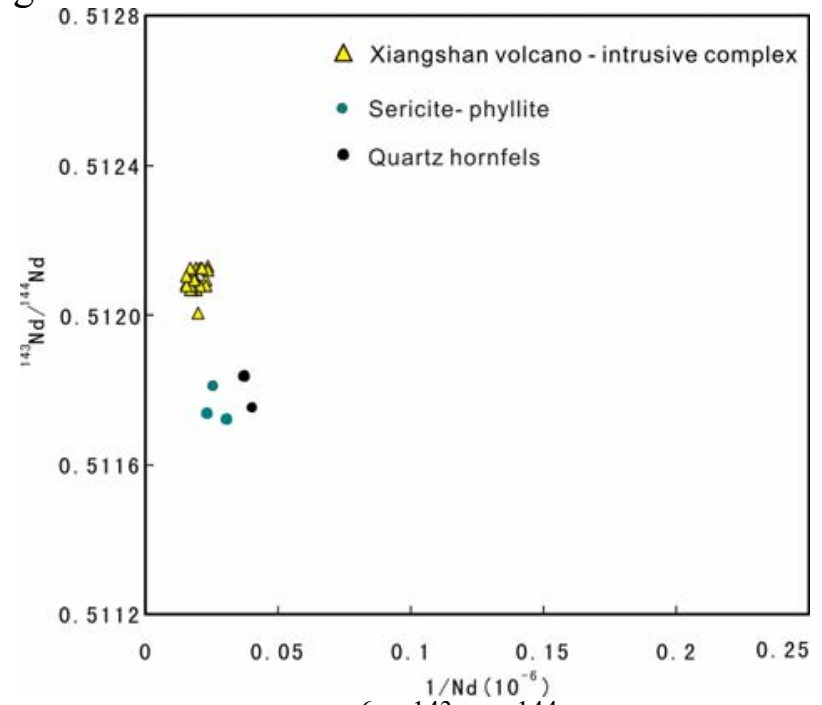

Fig. $111 / \mathrm{Nd}\left(10^{-6}\right)-{ }^{143} \mathrm{Nd} /{ }^{144} \mathrm{Nd}$ diagram

The content of Xiangshan volcano-intrusive complex and basement metamorphic rock changes obviously. This paper takes the volcano intrusive complex formation time $135 \mathrm{Ma}$ (dating average value of complex rock mass SIMS zircon $\mathrm{U}-\mathrm{Pb}$ ) to deduct the $\mathrm{Pb}$ of radioactive decay cause after diagenesis, and carries on discussion to the ratio of $\mathrm{Pb}$ isotope that was after being corrected.From the data listed in Table 2,the contents of Xiangshan basement metamorphic rock' $\mathrm{Pb}$ isotope and the volcano-intrusive complex' have great difference:the data of basement metamorphic rock' $\mathrm{s} \mathrm{Pb}$ isotope: ${ }^{206} \mathrm{~Pb} /{ }^{204} \mathrm{~Pb}=18.333 \sim 19.265,{ }^{207} \mathrm{~Pb} /{ }^{204} \mathrm{~Pb}=15.645 \sim 15.747,{ }^{208} \mathrm{~Pb} /{ }^{204} \mathrm{~Pb}=38.495 \sim 39.265$; the data of volcano-intrusive complex' $\mathrm{s}$ Pb isotope: ${ }^{206} \mathrm{~Pb} /{ }^{204} \mathrm{~Pb}=18.152 \sim 18.385,{ }^{207} \mathrm{~Pb} /{ }^{204} \mathrm{~Pb}=15.608 \sim$ 15.631, ${ }^{208} \mathrm{~Pb} /{ }^{204} \mathrm{~Pb}=38.445 \sim 38.755$. In the figure of the growth trajectory of the Lead isotope(Fig.12),the data of metamorphic sedimentary rock distribute in a large range,and they are located nearby the upper crustal evolution line in general,and the data of the volcano-intrusive complex is concentrated, and they distribute between the upper crust and orogenic belt. There are high lead isotope ratios of phyllite and low lead isotope ratios of the quartz hornstone.It shows that the content of the lead isotope was not uniform during the process of metemorphism, the ratios of lead isotope are different because of the different degree of metemorphism.In general, the lead isotope values of metamorphic sedimentary rock are higher that the values of complex body. 

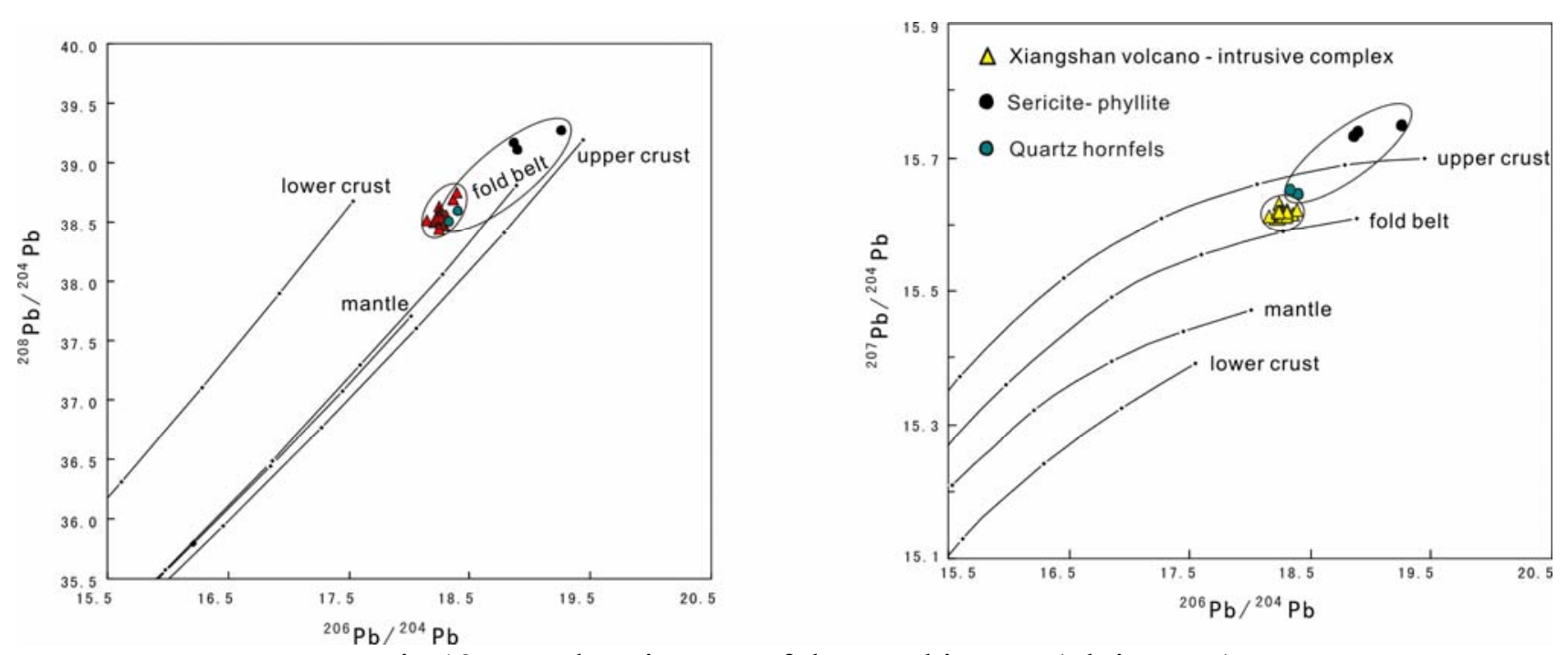

Fig.12 growth trajectory of the Lead isotope $(\mathrm{Pb}$ isotope $)$

The traits above show that the relationship that is between the volcano-intrusive complex and the basement metamorphic rock is not close.Certainly,it can not eliminate that the uranium is from metamorphic igneous rock, because the research only studied metamorphic sedimentary rock instead of metamorphic igneous rock.But the former researches show that the characteristics of Xiangshan volcano-intrusive complex body are focus on the characteristics of granite ${ }^{[39-45]}$. So even though uranium is from metamorphic igneous rock,there is also a few influence on it.The crustal material of the complex body that is from partial fusion should be the deeper material,this implies that there should be a storage cavern of uranium instead of basement metamorphic rocks in the deep of Xiangshan,and certain migmatization occurred to the storage cavern with magma during the process of complex rock forming, and eventually they emplaced-overflowed into rocks together.

\section{Conclusion}

(1)The original rock of Xiangshan Qingbaikouan basement metamorphic rock is mainly sandstone or graywacke with moderate maturity, and that formed in the inherited remnant-ocean basin which had island-arc or back-arc environment.

(2)In the figure of the Chondrite-normalized plots of REE, the basement metamorphic rock's content of LREE is slightly higher than the volcano-intrusive complex body's, they have different isotope values of $\mathrm{Pb}-\mathrm{Sr}-\mathrm{Nd}$ and $\mathrm{Nd}$ model ages, and it shows that they are loosely connected.

(3)There should be a storage cavern of uranium in the deep of Xiangshan,and certain migmatization occurred to the storage cavern with magma during the process of complex rock forming instead of the basement metamorphic rock that we can see on surface.

\section{Acknowledgements}

This work was financially supported by Three Dimensional Geological Mapping Pilot Project of China Geological survey (1212011220248); National Natural Science Foundation Project(41072077); Leading Talents Project of Jiangxi Province; the Principal Fund Project of ECIT(DHXK201403); Fundamental Science on Radioactive Geology and Exploration Technology Laboratort (RGET1402).

\section{References}

[1] Jinghua Xu, Shu Sun, Jiliang Li. 1987. It Is South China Orogenic Belt Rather Than South China Platform(in Chinese) .Science in China(Series B), 10:1107-1115(in Chinese).

[2] Jinghua Xu. 1980. Thin Shell Type Plate Tectonic Pattern and Collision Orogeny(in Chinese ).Science in China(Series B),11:1081-1089(in Chinese). 
[3] Qingkang Liao. 1991. Forming time of darongshan-shiiwandshan granite bathholith in Guangxi.Geology of Guangxi,4(4):59-68(in Chinese).

[4] Tianfeng Wan, Hong Zhu. 2002. Tectonics and environment change og meso-cenozoic in China continent and its adjacent areas. Geoscience,16(2):107-120(in Chinese).

[5] Tianfeng Wan. 2005. Teetonic Research of China. geological publishing house,Beijing,51-73(in Chinese).

[6] Tao Shui.1987.The structural pattern of continental basement of SE China. Science in China(Series B),(4):414-422(in Chinese).

[7] Xiaoming Chen, Jianjun Lu., Changshi Liu, Lianze Zhao, Dezi Wang, Huimin Li. 1999. Single grain zircon $\mathrm{U} \mathrm{Pb}$ isotopic ages of the volcanic intrusive complexes in Tonglu and Xiangshan areas.Acta Petrolgica Sinica, 15:272-278(in Chinese).

[8] Zejun Zhang, Zhi Zhang, Songxian Qin, Xiongfei Cai. 2003. Pre-Sinian basic tectonic framework of northern south China and its evolution.Geoscience,24(3):197-204(in Chinese).

[9] HuaiminXue, FangMa, YongqinSong, YapingXie. 2010. Chronology and Geochemistry of Combination of Neoproterozoic Granite in the Eastern Section of the Jiangnan Orogenic Belt: Constraints of Collision events' Time and Process about the Yangtze and Cathaysian Block (in Chinese).Acta Petrologica Sinica , 2010, 26(11): 3215-3244(in Chinese).

[10]Liangshu Shu. 2012. An analysis of principal features of tectonic evolution in South China Block. Geological Bulletin of China.Geological Bulletin Of China,31(7):1035-1953(in Chinese).

[11]Zhigang Shi. 2014. Neoproterozoic strata and tectonic evolution study in Lushan mountain (in Chinese ) .Doctoral dissertation of the Chinese academy of geological sciences,1-135(in Chinese).

[12] Gongrui $\mathrm{Hu}$, Congqiang Liu, Bangdong Zhang, Hongfeng Tang. 2004. Geochemical characteristics of meta-argillo-arenaceous rocks from the metamorphic rock belt in central Jiangxi Province and its geological significance. Acta Geoscientica Sinica,33(2):118-130(in Chinese).

[13]Xiyan Fang, Wenrao Hou, Guoliang Wan. 1982. Petrographic Studies of the Volcanic Complex in the Xiangshan Caldera.Rock and Mineral Analysis, 1:1-10(in Chinese).

[14] ChuanwenWang, WenyaoHou, GuoliangWan, XiyanFang. 1982.. The origin of porphyeoclastic lava and its characteristic in Xiangshan and its adjacent areas. Radioactive geology, 3:193-198(in Chinese)

[15]linyi Xia, Zuchun Xia, Cheng Zhang, Clocchiatti R, Dardel J, Joron J L. 1992. Petrogeochemistry of Mesozoic Uraniferous volcanic complex in Xiangshan.Beijing:geological publ. House ,1-35(in Chinese).

[16]Rengui Wu. 1999. The features of volcanic formation in Ruyiting Profile of Xiangshan.Journal of East China Geological Institute, 22:201-208(in Chinese).

[17]Jianhua Wu. 1999. A Discussion on the Lithostratigraphical Division of Continental Volcanic Terrain. Ceological Review, 45(Supplement):93-100(in Chinese).

[18]Honghai Fan, Hongfei Ling, Dezi Wang, Changshi Liu, Yaohui Jiang. 2001. Nd-Sr-Pb isotope geochemistry of the volcanic-intrusive complex at Xiangshan,Jiangxi province.Acta Petrologica Sinica, 17:395-402(in Chinese).

[19] Wanliang Zhang, Ziying Li. 2007. Single_zircon U_Pb age of rhyodacite from Xiangshan area and its geological implications.Acta Petrologica Et Mineralogica, 26:21-26(in Chinese). 
[20] Wanliang Zhang. 2005. Reverse magmatic evolution series of the Xiangshan volcanic intrusive complex.Chinese Geology , 32:548-556(in Chinese).

[21] Gongrui Hu, Bangdong Zhang. 1998. Geochemical study of uraniumin basement metamorphic roces of Xiangshan volcanic collapse basin.Uranium Geology,14(1):1-6(in Chinese).

[22] Aijin Qiu, Lingzhi Guo, Liangshu Shu, Dayu Zheng. 2001. Strike-slip pull-apart process and emplacement of Xiangshan uranium-producing volcanic basin.Uranium Geology,17(5):266-273(in Chinese).

[23]Hanbin Liu, Guishan Jin, Junjie Li, Juan Han, Jianfeng Zhang, Jia Zhang, Fangwen Zhong, Dongqiao Guo. 2013. Determination of stable isotope composition in uranium geological samples. World Nuclear Geoscience.30(3):174-179(in Chinese).

[24]Dongfa Guo, Chaohui Wu, Jianyong Cui, Guangxi Ou, Guang Fan. 2007. Review on uranium geoanalysis and introduction to the concept of network analytical laboratories. World Nuclear Geoscience.24(1):50-63(in Chinese).

[25]Roser B P, Korsh R J. 1986. Determination of tectonic setting of sandstone-mudstone suites using $\mathrm{SiO}_{2}$ content and $\mathrm{K}_{2} \mathrm{O} / \mathrm{Na}_{2} \mathrm{O}$ ration. The Jurnal of Geology, 94 (5): 623-648.

[26]Bhatia M R. 1983. Plate tectonics and geochemical composition of sandstones. Journal of Geology, 91:611-627.

[27] Bhatia M R. 1986. Rare earth element geochemistry of Australian Paleozoic graywacks and mudrocks : provenance and tectonic control.Sedimentary Geology, 45: 97-113.

[28] Nance W B, Taylor S R. 1976. Rare earth element patterns and crustal evolution I: Australian post-Archean sedimentary rocks. Geochimica et Cosmochimica Acta, 40: 1539-1551.

[29] Qiuju Qi, Zhaochong Zhang, Shuyun Dong, Dongyang Zhang, He Huang, Shu Zhang, Letian Ma. 2011. Geochemical characteristics and tectonic setting of Mesoproterozoic metamorphic rocks in Aksu area, Southwestern Tianshan Mountains.Acta Petrologica Et Mineralogica,30(2):172-184(in Chinese).

[30]Hongfu Yin, Shunbao Wu, Yuansheng Du, Yuanqiao Peng. 1999. South China defined as part of tethyan archipelagic ocean system.earth science,24(1):1-12(in Chinese).

[31] Asahara Y, Tanaka T, Kamioka H, Nishimura A, Yamazaki T. 1999. Provenance of the north Pacific sediments and process of source material transport as derived from $\mathrm{Rb}-\mathrm{Sr}$ isotopic systematics. Chemical Geology, 158:271-291.

[32]Borg L E, Banner J L. 1996. Neodymium and strontium isotopic constraints on soil sources in Barbados, West Indies. Geochimica et Cosmochimica Acta, 60: 4193-4206

[33] Martin C E, McCulloch M T. 1999. Nd-Sr isotopic and trace element geochemistry of river sediments and soils in a fertilized catchment, New South Wales, Australia. Geochimica et Cosmochimica Acta, 63:287-305.

[34]Jiedong Yang, Jun Chen, Zhaofeng Zhang, JunfengJi, YangChen. 2005. Variations in ${ }^{143} \mathrm{Nd} /{ }^{144} \mathrm{Nd}$ and ${ }^{87} \mathrm{Sr} /{ }^{86} \mathrm{Sr}$ of Lingtai profile over the past $7 \mathrm{Ma}$. Geochemica, 2005, 34(1): 1-6(in Chinese).

[35] Goldstein S L, O’Nions R K, Hamilton P J. 1984. A Sm-Nd isotopic study of atmospheric dusts and particulates from major river systems. Earth and Planetary Science Letters, 70: 221-236.

[36] Goldstein S J, Jacobsen S B. 1988. Nd and Sr isotopic systematics of river water suspended material: implication for crustal evolution. Earth and Planetary Science Letters, 87: 249-265. 
[37] Shuguang Li, Deliang Liu, Yizhi Chen, Zongqing Zhang. 1994. Neodymium isotopic compositions of continental crust in the northern margin of Yangtze block and its tectonic implications.Geochimica, 1994, 23(Supplement): 10-17(in Chinese).

[38]Xianhua Li, McCulloch M T. 1996. Nd IsotoPic Evoluttonof Sediments from the Southern Margin of the Yangtze Block and Its Tectonic Significance.Acta Petrologica Sinica,12(3): 360-369(in Chinese).

[39] Jiayuan Liu. 1985. Xiangshan igneous pluton-a granitic hypabyssal intrusive volcanic vomplex. Geochimica, 14:142-149(in Chinese).

[40]Dezi Wang, Changshi Liu, Weizhou Shen, Fanrong Chen. 1991. The geology discovery and significance of Mesozoic S-type volcanic rocks zone in Dongxiang-Xiangshan, Jiangxi(in Chinese).Chinese Science Bulletin,36(19):1491-1493(in Chinese).

[41]Dezi Wang, Changshi Liu, Weizhou Shen, Fanrong Chen. 1993. The contrast between Tonglu I-type and Xiangshan S-type clastoporphyritic lava. Acta Perrologica Sina,9:44-54(in Chinese).

[42] Changshi Liu, Jinchu Zhu, Weizhou Shen, Shijin Xu, XinyiYang. 1990. Evolution of continental crust and material source(genesis) of granitoids in S.China. Geotectonica et Metallogenia,2(14):395-402(in Chinese).

[43]Bangda Li. 1993. The origin of porphyroclastic lava and its control over uranium depqsits in Xiangshan,Jiangxi-a discussion. Geologcial Review,39:101-110(in Chinese).

[44] Yun Duan, Lianze Zhao, Honghai Fan, Dezi Wang,2001.Ree-Geochemistry of Mesozoic Volcanic-Intrusive Complex and Dark Inclusions in Xiangshan District, Jiangxi Pronvince.Geological Journal of China Universiies, 7:92-98(in Chinese).

[45]Xiaoping Dou. 2005. Ree distribution characteristics of volcanic and epimetamorphic rocks in Xiangshan volcanic basin and discussion on their genesis.Uranium Geology, 21:338-344(in Chinese). 